\title{
$1: 163791526-163753740$
}

National Cancer Institute

\section{Source}

National Cancer Institute. 1: 163791526-163753740. NCI Thesaurus. Code C42404.

Physical location of GPA33_Gene 